Sharif University of Technology
Scientia Iranica
SCIENTIA
IRAN I CA
http://scientiairanica.sharif.edu

\title{
Riprap design at bridge piers with limited scouring
}

\author{
Gh. Khademghaeiny ${ }^{a}$, J. Abrishami ${ }^{a}$, A.R. Zarrati ${ }^{b, *}$, M. Karimaei Tabarestani ${ }^{c}$, \\ and M. Mashahir ${ }^{b}$ \\ a. Department of Civil Engineering, Ferdowsi University, Mashhad, Iran. \\ b. Department of Civil and Environmental Engineering, Amirkabir University of Technology, Tehran, P.O. Box 15915, Iran. \\ c. Department of Civil Engineering, Shahid Rajaee Teacher Training University, Lavizan, Tehran, P.O. Box 16785-163, Iran.
}

Received 13 August 2017; received in revised form 10 March 2018; accepted 17 December 2018

\section{KEYWORDS \\ Bridge piers; \\ Local scour; \\ Riprap protection; \\ Round and angular \\ riprap; \\ Limited scouring.}

\begin{abstract}
One of the common methods for scour protection around bridge piers is riprap layer. In previous studies, sizing riprap layer was used to ensure $100 \%$ protection against scouring. However, in many cases, limited scour depth around a pier may be accepted if only smaller riprap sizes are available. In the present work, the effects of the smaller size of riprap stones compared to their stable size on the scour depth around a bridge pier were studied. Circular and oval shapes for riprap extent and both round and angular stone shapes were also tested. All tests were conducted at the threshold of bed sediment motion, and the maximum scour depth was measured. The results of these experiments showed that with stone sizes closer to stable riprap material, the efficiency of both round and angular stone shapes was identical. As the size of riprap reduced, deeper scour holes were observed with both round and angular shape materials. The results also indicated that increasing the extent of the riprap layer from circular to oval with 5 times more riprap volume had insignificant effects on scour hole for angular shape riprap and, also, reduced the scour hole depth with round shape material. Based on experimental data, a method was developed to calculate a smaller riprap size based on an accepted limited scour hole.

(C) 2020 Sharif University of Technology. All rights reserved.
\end{abstract}

\section{Introduction}

Local scour around a pier results from a complex vortex system that forms around the pier. These vortices consist of a horseshoe vortex initiated from the down flow at the upstream face of the pier and wake vortices downstream of the separation point at the sides of the pier $[1,2]$. There are many methods to control scouring around bridge piers: these methods include

\footnotetext{
*. Corresponding author. Tel.: +982164543002;

Fax: +982166414213

E-mail addresses: nabi.khadem@yahoo.com (Gh.

Khademghaeiny); j-abrishami@um.ac.ir (J. Abrishami);

Zarrati@aut.ac.ir (A.R.Zarrati); Karimaei@srttu.edu. (M.

KarimaeiTabarestani); m.b.mashahir@aut.ac.ir (M.

Mashahir)
}

doi: $10.24200 /$ sci.2018.5005.1037 devices that change the flow pattern to reduce the flow force such as collars [3,4], sacrificial piles placed upstream of the pier [5], slots [6], and vanes [7,8]; in addition, there are a number of methods that increase streambed resistance such as riprap stones, cable-tied blocks, tetrapods, dolos, etc. [9-17].

Previous studies have shown that, under clear water conditions, three failure mechanisms may occur:

1. Shear failure, where riprap stones are entrained by the flow;

2. Winnowing failure, where the finer under-laying bed material is eroded between the riprap stones;

3. Eedge failure, where scouring at the periphery of the riprap layer undermines the armor stones [9].

In addition, Chiew and Lim (2000) [18] and Chiew (2004) [19] identified another failure mechanism for 
riprap in live bed conditions, where the riprap layer is destabilized by the bed forms and bed degradation past the pier.

The application of riprap as an armoring device to protect bridge piers from scouring is common in civil engineering practice. Many experimental research studies have been carried out to determine the riprap size and extent around bridge piers [9,10,13-21]. Most of these studies have been conducted under clear water conditions, in which the size of the stable riprap layer correlates only with the approach flow velocity or shear velocity. However, based on a large amount of experimental data, Karimaei Tabarestani and Zarrati (2013) [13] and Karimaei Tabarestani et al. (2015b) [15] presented a new equation including most of the important factors in riprap stability. This equation, which can be used for designing stable riprap around aligned and skewed round-nose rectangular and circular piers, is as follows:

$$
N_{c}=2.85 \times K_{1} \times K_{2} \times K_{3} \times K_{4},
$$

where $N_{c}$ is the riprap stability number that indicates the relationship between the flow condition and riprap stone characteristics and can be written as follows:

$$
N_{c}=\frac{\rho \cdot U^{2}}{g \cdot\left(\rho_{s}-\rho\right) \cdot D_{50}}
$$

where:

$\begin{array}{ll}U & \text { The undisturbed upstream depth- } \\ & \text { averaged flow velocity; } \\ D_{50} & \text { Median size of stable riprap stones; } \\ g & \text { Gravitational acceleration; } \\ \rho & \text { Fluid density; } \\ \rho_{s} & \text { Riprap stone density. }\end{array}$

In addition, square root of $N_{c}$ is called the Densimetric Particle Froude Number, which was also used by some studies as an essential parameter that affects scour depth around hydraulic structures [22,23]. Comparison of Eq. (1) and many other riprap design equations can be found in [13].

In Eq. (1), $K_{1}=\sqrt{D_{50} / B}$ is the riprap size adjustment factor, where $B$ is the round-nose rectangular pier width or circular pier diameter; $K_{2}=\left(y / D_{50}\right)^{0.25}$ is the flow depth adjustment factor; $K_{3}=\left(B / B_{\text {eff }}\right)^{1.5}$ is the pier effective width adjustment factor, where $B_{\text {eff }}$ is equal to circular pier diameter or projected length of the rectangular pier perpendicular to the flow direction and is defined as $B_{\text {eff }}=L \times \sin \theta+B \times(1-\sin \theta)$, where $L$ is the rectangular pier length and $\theta$ is the pier skew angle. For circular and aligned rectangular piers, $B_{\text {eff }}=B$. Finally, $K_{4}$ is the collar adjustment factor which is $K_{4}=1$ in the case of no protective collar installation [15]. The accuracy of Eq. (1) has been reported in different studies [13-16]. For riprap design in clear water conditions, winnowing failure can be prevented by either a filter layer between riprap and river deb sediment or placing sufficient riprap thickness. Different studies indicated that minimum riprap thickness for preventing winnowing failure is $2.5 D_{50}$. Finally, riprap edge failure can be prevented by sufficient riprap extent around the bridge pier. In the literature, oval and circular shapes for riprap extent around bridge pier have been presented. Chiew (1995) [9] suggested that the radius of circular extent for riprap layer could be selected equal to $2.5 \mathrm{~B}$. In addition, investigations by Garde and Ranga Raju (1977) [24] showed that the extension of riprap layer at downstream of bridge pier must be $5 B$ for oval shape. Figure 1 shows the definition sketch for riprap cover extent around a circular pier.

In all previous studies, the design of riprap layer accounted for $100 \%$ protection against scour. However, in many cases, a limited scour hole around a pier may be accepted. Therefore, a more economical design may be achieved with smaller riprap size and cover area accepting a limited depth of the scour hole corresponding to the piers foundation depth. In the present work, experiments were carried out in clear water conditions with different riprap sizes, shapes, and extent in order to study the effect of the smaller size of riprap stones compared to their stable size on the scour depth around a bridge pier.

\section{Experimental setup}

Experiments were conducted in a $12 \mathrm{~m}$ long, $0.3 \mathrm{~m}$ wide glass-walled horizontal flume. The flume is characterized by a $0.15 \mathrm{~m}$ high and $1.5 \mathrm{~m}$ long working section in the form of a recess below its bed, filled with sediment of $0.85 \mathrm{~mm}$ in median size and density of $2650\left(\mathrm{~kg} / \mathrm{m}^{3}\right)$. The geometric standard deviation of bed sediment grading $\sigma_{g}=\sqrt{d_{84} / d_{16}}$ is 1.2 , where $d_{84}=0.94 \mathrm{~mm}$ and $d_{16}=0.65 \mathrm{~mm}$ are respectively the sizes of sediment for which $84 \%$ and $16 \%$ of material by weight are finer. The value of $\sigma_{g}$ implies that the sediment sample is uniform. The working section starts $6 \mathrm{~m}$ downstream from the flume inlet, where the boundary layer has been fully developed. The absolute roughness of the false bed is about $1 \mathrm{~mm}$. The pier

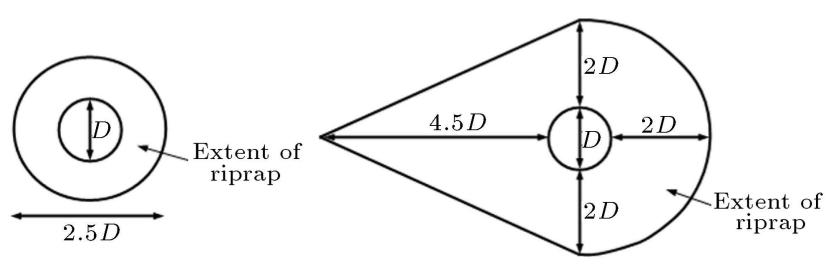

(a) Circular

(b) Oval

Figure 1. Definition sketch for riprap cover extent. 
model is made of a $30 \mathrm{~mm}$ diameter clear Perspex tube. The distance between the pier center and the side wall is, therefore, 5 times the pier diameter. The effect of flume side walls is negligible, given the aforementioned distance [25].

All tests were conducted at the threshold of bed material motion. The threshold of bed material motion was found by an experiment when the pier was not installed. The threshold of material motion is defined as the condition in which finer materials may move, but the elevation of the bed does not reduce by no more than 2 to $3 \mathrm{~mm}$ during 10 hours test. The ratio of shear velocity $\left(u_{*}\right)$ in these experiments calculated from flow depth and energy slope to the threshold shear velocity $\left(u_{* c}\right)$ through Shields diagram is about 0.93 .

The flow depth was measured with a point gauge of $0.1 \mathrm{~mm}$ accuracy. A rectangular sharp crested weir with a manometer was used to measure the flow discharge at the flume end. The pier model was scaled, and the scour hole depth at the pier perimeter was measured with $1 \mathrm{~mm}$ accuracy using a periscope installed inside the pier.

In the present study, Eq. (1) was used for riprap design around a bridge pier model with respect to the flow condition. Calculations showed that the size of stable riprap stone for complete protection of the streambed against local scouring was equal to $4.5 \mathrm{~mm}$ for the present experimental setup. Based on this result, four sizes of stones equal to $2.5 \mathrm{~mm}, 3 \mathrm{~mm}$, $4 \mathrm{~mm}$, and $4.5 \mathrm{~mm}$ were selected as riprap materials. Table 1 shows the properties of different riprap stones. As shown in this table, two series of tests were carried out with two different types of riprap: almost round and angular stone shapes, where the shape factors of these grains were 0.7 to 0.62 and 0.54 to 0.425 respectively. Shape Factor is defined as $S F=\frac{e}{\sqrt{a b}}$, where $a, b$, and $e$ are the largest, intermediate, and smallest dimensions of a stone measured along the three mutually perpendicular axes, respectively. The

Table 1. Properties of riprap material.

\begin{tabular}{|c|c|c|c|c|}
\hline $\begin{array}{c}D_{50} \\
(\mathrm{~mm})\end{array}$ & $\sigma$ & $\begin{array}{c}\text { Riprap } \\
\text { shapes }\end{array}$ & $\begin{array}{c}\rho_{s} \\
\left(\mathrm{~kg} / \mathrm{m}^{3}\right)\end{array}$ & $\begin{array}{l}\text { Shape } \\
\text { factor }\end{array}$ \\
\hline \multirow{2}{*}{2.5} & \multirow{2}{*}{1.23} & Angular & 2800 & $0.425-0.54$ \\
\hline & & Round & 2730 & $0.62-0.7$ \\
\hline \multirow{2}{*}{3} & \multirow{2}{*}{1.25} & Angular & 2800 & $0.425-0.54$ \\
\hline & & Round & 2730 & $0.62-0.7$ \\
\hline \multirow{2}{*}{4} & \multirow{2}{*}{1.28} & Angular & 2800 & $0.425-0.54$ \\
\hline & & Round & 2730 & $0.62-0.7$ \\
\hline \multirow{2}{*}{4.5} & \multirow{2}{*}{1.3} & Angular & 2800 & $0.425-0.54$ \\
\hline & & Round & 2730 & $0.62-0.7$ \\
\hline
\end{tabular}

geometric standard deviation of sediment grading $\left(\sigma_{g}\right)$ for each riprap size is less than 1.3, implying that the sample is uniform.

Two different shapes of riprap extent around the pier were also used: i) circular and ii) oval (Figure 1). The top surface of the riprap layer was leveled with the undisturbed bed elevation. To prevent winnowing failure at the beginning of the experiment, the thickness of riprap layer $t_{r}$ in all tests was $2.5 D_{50}$ [9]. In addition, a screen with a sieve size of $0.3 \mathrm{~mm}$ was used between the bed and riprap materials as a filter.

To insert the riprap layer of predetermined cover shape and thickness, a ring with the same extent as the riprap cover was first embedded around the pier model, and the bed material inside the ring was removed. The hole was then filled with riprap and leveled carefully with the approach streambed level. Finally, the ring was removed.

Figure 2 shows time development of maximum scour depth at the upstream face of the pier without any protection and with riprap protection of various sizes and shapes. In this figure, $d_{s t}$ is the scour depth at time $t$ and $d_{s f}$ is the final scour depth. According to Figure 2, for piers with insufficient riprap protection, the rate of scouring was very low after 10 hours, and scouring after 24 hours was negligible because riprap stones falling into the scour hole protect it from further scouring. Based on these results, all tests were conducted in 24 hours.

\section{Number of experiments}

After a preliminary test with an unprotected pier, experiments were first conducted with four sizes of riprap stones through the circular extension of the riprap layer. These tests were carried out with both round and angular shape riprap materials. In addition to these eight tests, four additional experiments were

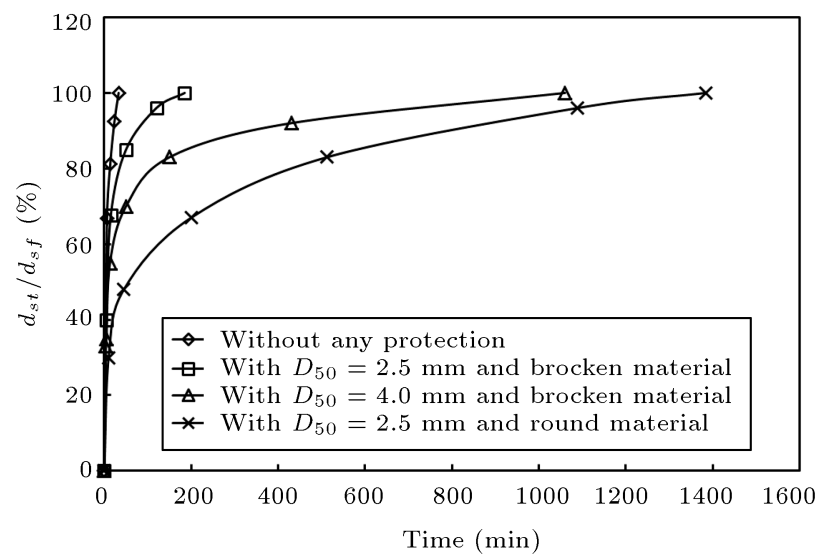

Figure 2. Time development of scouring with and without protection and with different riprap material (circular extent). 
performed with the smallest and largest round and angular riprap sizes with oval shape extension of the riprap layer. All 12 tests were carried out in 24 hours. A summary of all conducted experiments is given in Table 2. In this table, $U / U_{c}$ is the flow intensity parameter, which is the where $R_{h}$ is the hydraulic radius. In addition, $N_{c}$ in Table 2 is calculated through Eq. (2). ratio of flow velocity to the threshold velocity for the riprap stones. Parameter $U_{c}$ is determined using the mean velocity equation for a rough bed [9]:

$$
\frac{U_{c}}{u_{* c}}=5.75 \log \left(\frac{R_{h}}{d_{90}}\right)+6.25 .
$$

\subsection{Unprotected pier}

In a preliminary test, scour depth was measured around the pier without any protection. The test lasted for 10 hours, and equilibrium relative scour depth was measured $d_{s e} / B=2.17\left(d_{s e}=6.5 \mathrm{~cm}\right)$ at the upstream face of the pier. The equilibrium scour depth was in agreement with the empirical equations (for example, Melville and Sutherland (1988) [26]). The scour hole around the pier was also symmetric, showing the evenness of flow and correct setup of the experiment.

3.2. Angular riprap stones with circular extent Table 3 shows the results of experiments for the angular riprap stone. In this table, the equilibrium scour depth $\left(d_{s}\right)$, the relative scour depth $\left(d_{s} / B\right)$, and the ratio of

Table 2. Experimental conditions in the present study.

\begin{tabular}{cccccc}
\hline No. & $\begin{array}{c}\boldsymbol{D}_{\mathbf{5 0}} \\
(\mathbf{m m})\end{array}$ & $\begin{array}{c}\text { Riprap } \\
\text { shapes }\end{array}$ & $\begin{array}{c}\text { Riprap } \\
\text { extent }\end{array}$ & $\boldsymbol{U} / \boldsymbol{U}_{\boldsymbol{c}}$ & $\boldsymbol{N}_{\boldsymbol{c}}$ \\
\hline 1 & 2.5 & Angular & Circular & 0.54 & 2.89 \\
2 & 3 & Angular & Circular & 0.50 & 2.41 \\
3 & 4 & Angular & Circular & 0.44 & 1.81 \\
4 & 4.5 & Angular & Circular & 0.41 & 1.61 \\
5 & 2.5 & Round & Circular & 0.56 & 3.01 \\
6 & 3 & Round & Circular & 0.51 & 2.51 \\
7 & 4 & Round & Circular & 0.45 & 1.88 \\
8 & 4.5 & Round & Circular & 0.42 & 1.67 \\
9 & 2.5 & Angular & Oval & 0.54 & 2.89 \\
10 & 2.5 & Round & Oval & 0.56 & 3.01 \\
11 & 4.5 & Angular & Oval & 0.37 & 1.61 \\
12 & 4.5 & Round & Oval & 0.38 & 1.67 \\
\hline
\end{tabular}

Table 3. Scour depth results with angular shape riprap stones and circular extent.

\begin{tabular}{ccccccc}
\hline $\begin{array}{c}\boldsymbol{D}_{\mathbf{5 0}} \\
(\mathbf{m m})\end{array}$ & $\boldsymbol{B} / \boldsymbol{D}_{\mathbf{5 0}}$ & $\boldsymbol{N}_{\boldsymbol{c}}$ & $\begin{array}{c}\boldsymbol{d}_{\boldsymbol{s}} \\
(\mathbf{c m})\end{array}$ & $\boldsymbol{d}_{\boldsymbol{s}} / \boldsymbol{B}$ & $\begin{array}{c}\boldsymbol{d}_{\boldsymbol{s}} / \boldsymbol{d}_{\boldsymbol{s e}} \\
(\boldsymbol{\%})\end{array}$ & $\boldsymbol{K}_{\mathbf{5}}$ \\
\hline 2.5 & 12 & 2.89 & 3.2 & 1.07 & 49 & 1.8 \\
3 & 10 & 2.41 & 2.2 & 0.73 & 33 & 1.5 \\
4 & 7.5 & 1.81 & 0.9 & 0.30 & 14 & 1.13 \\
4.5 & 6.67 & 1.61 & 0 & 0 & 0 & 1 \\
\hline
\end{tabular}

scour depth to unprotected pier scour depth $\left(d_{s} / d_{s e}\right)$ are shown. In addition, parameter $K_{5}$, which is the ratio of parameter $N_{c}$ for smaller riprap size to design riprap size $\left(D_{50}=4.5 \mathrm{~mm}\right)$, is also shown in this table.

\section{Experimental results}

Experimental observations showed that, for riprap with $B / D_{50}=12\left(D_{50}=2.5 \mathrm{~mm}\right)$, the vortex systems that formed around the pier de-stabilized the riprap stones. At the beginning of the experiment, the down flow at the upstream face of the pier impinged on the riprap materials and removed them in the downstream direction. In addition, at the downstream of the pier, wake vortices lifted and removed the riprap stones from the bed. When some of riprap stones were removed, the bed material was washed out and a scour hole was formed around the pier. With the development of the scour hole, the remaining riprap stones slid into the scour hole and, then, armored and prevented the hole from further scouring. This test continued for 24 hours after which the variations of the scour depth were found insignificant (Figure 2). Maximum relative scour depth $\left(d_{s} / B\right)$ observed in this experiment was 1.07 at the upstream face of the pier (Table 2). The results showed that although riprap layer failed and scouring occurred around the pier, the final depth of the scour hole was about $50 \%$ less than the depth of the scour hole in the pier without any protection.

In the next stage, the riprap size increased first to $B / D_{50}=10\left(D_{50}=3 \mathrm{~mm}\right)$ and, then, to $B / D_{50}=7.5$ $\left(D_{50}=4 \mathrm{~mm}\right)$ with $N_{c}=2.41$ and 1.81 , respectively, and experiments were performed with the same flow condition. Similar to the first test, some of riprap stones were removed due to the action of down flow and vortex systems around the pier. However, the scouring stopped after riprap stones slid into the scour hole and stabilized it. In these experiments, after 24 hours, the final scour depth was $33 \%$ and $14 \%$ of the scour hole depth of the unprotected pier $\left(d_{s} / d_{s e}=33 \%\right.$ and $\left.14 \%\right)$ for the relative riprap size of $B / D_{50}=10$ and 7.5 , respectively (Table 3 ). Figure 3 shows the scour hole around the pier with angular riprap stones and circular extent.

After these tests, the stable riprap size was tested with $B / D_{50}=6.67\left(D_{50}=4.5 \mathrm{~mm}\right)$ and $N c=1.61$ (Table 2). In this test, the riprap stones around the pier remained stable and no scouring was observed around the pier after 24 hours $\left(d_{s} / d_{s e}=0\right.$ in Table 3$)$.

\subsection{Round riprap stones with circular extent}

To compare angular material with others, the same four sizes of riprap stones, i.e., $2.5 \mathrm{~mm}, 3 \mathrm{~mm}, 4 \mathrm{~mm}$, and $4.5 \mathrm{~mm}\left(N_{c}=3.01\right.$ to 1.67$)$, were also tested with round shape materials. The shape factor of these materials was between 0.62 and 0.7 . In these 


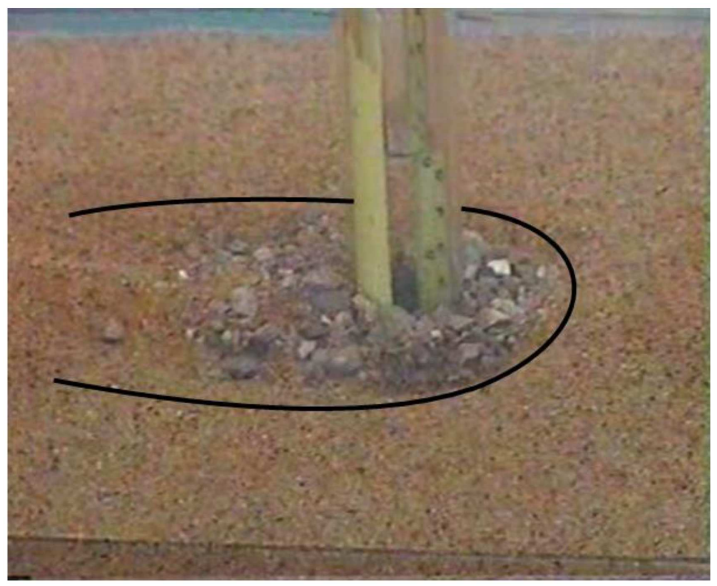

Figure 3. Scour hole around the pier with angular shape riprap material and circular extent (black line shows the boundary of the scour hole).

experiments, the extent of riprap layers and flow condition were similar to tests with an angular riprap. As is shown in Table 4, with these sizes of riprap stones, $\mathrm{ds} / \mathrm{dse}$ is $66 \%, 39 \%$, and $15 \%$, respectively. Similar to angular riprap, no scouring was observed with $4.5 \mathrm{~mm}$ riprap size. A sample of the scour hole around the pier with round shape riprap stones and circular extent is shown in Figure 4.

A comparison between results of experiments in

Table 4. Scour depth results with round shape riprap and circular extent.

\begin{tabular}{cccccc}
\hline $\begin{array}{c}\boldsymbol{D}_{\mathbf{5 0}} \\
(\mathbf{m m})\end{array}$ & $\boldsymbol{B} / \boldsymbol{D}_{\mathbf{5 0}}$ & $\boldsymbol{N}_{\boldsymbol{c}}$ & $\begin{array}{c}\boldsymbol{d}_{\boldsymbol{s}} \\
(\mathbf{c m})\end{array}$ & $\begin{array}{c}\boldsymbol{d}_{\boldsymbol{s}} / \boldsymbol{d}_{\boldsymbol{s e}} \\
(\boldsymbol{\%})\end{array}$ & $\boldsymbol{K}_{\mathbf{5}}$ \\
\hline 2.5 & 12 & 3.01 & 4.3 & 66 & 1.8 \\
3 & 10 & 2.51 & 2.5 & 39 & 1.5 \\
4 & 7.5 & 1.88 & 1.0 & 15 & 1.13 \\
4.5 & 6.67 & 1.67 & 0 & 0 & 1 \\
\hline
\end{tabular}

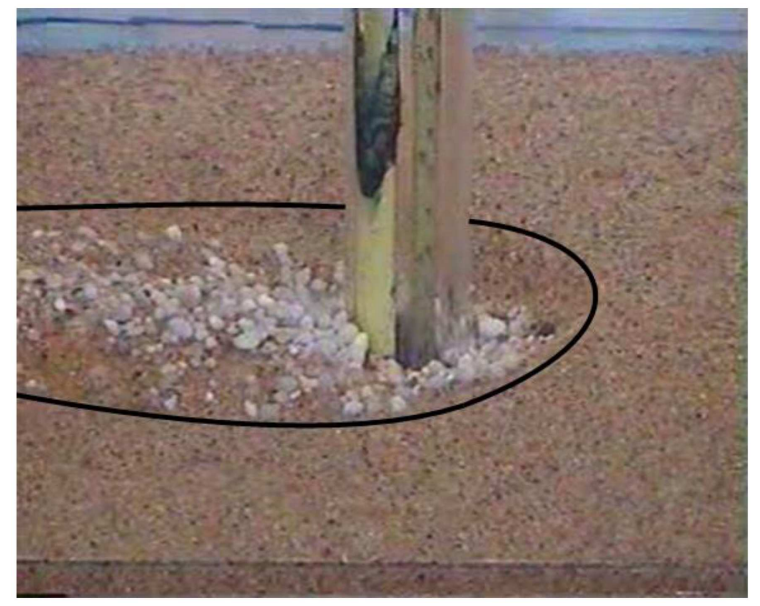

Figure 4. Scour hole around pier with round shape riprap material and circular extent (black line shows the boundary of the scour hole). the case of angular and round shape riprap materials demonstrates that the efficiency of round material is similar to that of angular material except in smaller sizes of riprap stones. For $2.5 \mathrm{~mm}$ riprap stones, the scour depth was about $25 \%$ greater in round riprap materials than that in angular stones. Round shape stone materials are usually available in river deposits. It can, therefore, be concluded that, with smaller riprap sizes (higher $N_{c}$ ), angular materials could further reduce the scour depth.

\subsection{Angular and round shape riprap stones with oval extent}

Two more tests were performed with the smallest riprap size of $2.5 \mathrm{~mm}$ in oval extent to investigate the effect of a larger riprap layer on the depth of the scour hole. Both angular and round shape materials were used in these tests. The oval extent is shown in Figure 1(b), and the results are summarized in Table 5. The results of these tests show that, with angular material, $d_{s} / d_{s e}$ is $43 \%$ in oval extent, which is close to $49 \%$ in circular riprap extent. However, with round shape stone material, $d_{s} / d_{s e}$ is $43 \%$ in oval extent, whereas it is $66 \%$ in circular extent with the same material, showing a $35 \%$ reduction in the scour depth. It can, therefore, be concluded that, with smaller riprap sizes (higher $N_{c}$ ), if angular shape material is used, larger extent of riprap material does not reduce the maximum scour depth much. However, with round shape material and smaller riprap size, larger extent of riprap layer is required to reduce the depth of the scour hole. The oval extent of the riprap layer used here has 5 times more volume of riprap than the circular extent.

\section{Design of smaller riprap with scour hole}

According to Eq. (1), riprap stones are predicted to account for a $100 \%$ protection against scour around the pier. However, present experimental data were used to determine a smaller riprap size based on an accepted limited scour hole. Therefore, Eq. (1) can be rewritten as follows:

$$
N_{c}=2.85 \times K_{1} \times K_{2} \times K_{3} \times K_{4} \times K_{5},
$$

where $K_{5}$ is the scour depth adjustment factor for riprap design, which can be found in Tables 3 to 5

Table 5. Scour depth results with round and angular shape ripraps and oval extent.

\begin{tabular}{lcccc}
\hline $\begin{array}{c}\text { Riprap } \\
\text { shapes }\end{array}$ & $\begin{array}{c}\boldsymbol{D}_{\mathbf{5 0}} \\
(\mathbf{m m})\end{array}$ & $\boldsymbol{N}_{\boldsymbol{c}}$ & $\begin{array}{c}\boldsymbol{d}_{\boldsymbol{s}} \\
(\mathbf{c m})\end{array}$ & $\begin{array}{c}\boldsymbol{d}_{\boldsymbol{s}} / \boldsymbol{d}_{\boldsymbol{s e}} \\
(\boldsymbol{\%})\end{array}$ \\
\hline Angular & 2.5 & 2.89 & 2.8 & 43 \\
Round & 2.5 & 3.01 & 2.8 & 43 \\
Angular & 4.5 & 1.61 & 0 & 0 \\
Round & 4.5 & 1.67 & 0 & 0 \\
\hline
\end{tabular}


based on $d_{s} / d_{s e}$. In the present experimental data, this parameter was calculated as a ratio of parameter $N_{c}$ for smaller riprap size to the design riprap size ( $D_{50}=4.5 \mathrm{~mm}$ in the present study). Experimental results showed that the value of $K_{5}$ could be calculated based on 3 different conditions:

1. For round and angular shape ripraps with oval extent (Table 5);

2. For angular shape riprap with circular extent (Table 3);

3. For round shape riprap with circular extent (Table 4).

Figure 5 shows the variation of $K_{5}$ with $d_{s} / d_{s e}$ for these three conditions. Based on the regression analysis of experimental data, the following equations are determined for calculating $K_{5}$ :

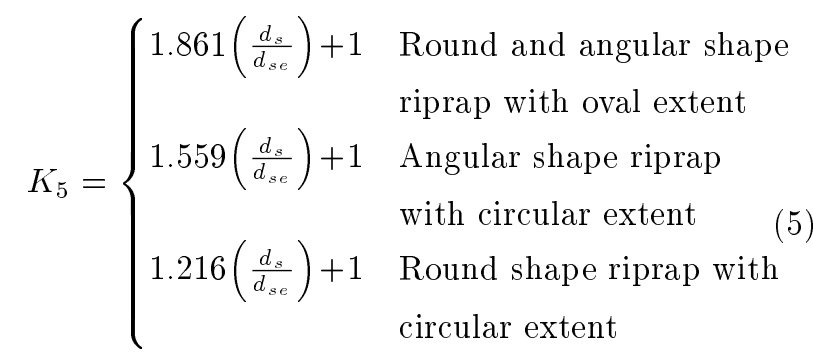

According to the present experimental data, the range of $d_{s} / d_{s e}$ in the above equations should be $0 \leq d_{s} / d_{s e}<$ 0.7. In addition, as is shown in Figure 5, the accuracy of these equations in predicting experimental data is very high with regression coefficient almost equal to 1 .

Two examples are presented here to illustrate how the present method can be used to estimate the riprap size finer than the calculated stable size based on the considered scour hole. Table 6 summarizes the measured undisturbed upstream flow depth $(y)$ and velocity $(V)$ together with pier width $(B)$ at two bridges: one over Homochitto River and another over

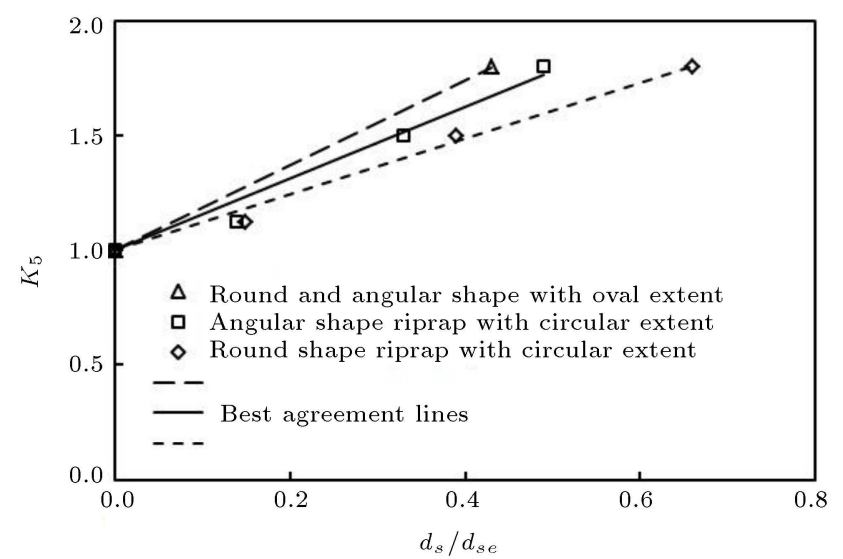

Figure 5. Variation of $K_{5}$ with $d_{s} / d_{s e}$ for different riprap conditions.
Table 6. Field conditions at selected bridge sites [9].

\begin{tabular}{lccc}
\hline \multicolumn{1}{c}{ Bridge site } & $\boldsymbol{y}(\mathbf{m})$ & $\boldsymbol{U}(\mathbf{m} / \mathbf{s})$ & $\boldsymbol{B}(\mathbf{m})$ \\
\hline Homochitto River & 3.8 & 2 & 2.44 \\
Brazos River & 10.4 & 1.1 & 3.50 \\
\hline
\end{tabular}

Brazos River. These conditions are assumed to be design conditions for the respective sites in the case studies. The details of these bridge sites can be found in Chiew (1995) [9]. From Table 6, stable riprap sizes were calculated for these two bridges by using Eq. (4). Results showed that the stable riprap sizes $\left(d_{s} / d_{s e}=0\right)$ with $\rho_{s}=2650 \mathrm{~kg} / \mathrm{m}^{3}$ in these two bridge sites were calculated as about $155 \mathrm{~mm}$ and $56 \mathrm{~mm}$, respectively. Now, the question is that what will be the riprap size if a limited scour hole equal to $d_{s} / d_{s e}=0.1,0.2,0.3$, and 0.5 is considered as a design criterion. Table 7 shows the results of riprap size based on angular or round shape riprap stones and oval or circular riprap extent. Results showed that, in both examples concerning the oval extent riprap layer, by considering $50 \%$ of equilibrium scour depth at the bridge site, the stable riprap size can decrease by about $40 \%$. In this case, for circular extent, the riprap size can be decreased by about $37 \%$ and $32 \%$ for angular and round shape stones, respectively. It is, therefore, possible for design engineers to decide on the riprap size based on economy- and/or constructionwise restrictions.

\section{Conclusion}

Determining riprap layer based on accepted limited scouring may be economical in engineering designs. In the present study, the scour depth around riprap stones smaller than stable riprap size was studied experimentally. The effect of riprap particle shape and extent around a cylindrical bridge pier on the scour hole depth was also investigated. Tests were conducted with 4 sizes of riprap stones with relative size $B / D_{50}$ between 6.67 and 12. All experiments were conducted at the threshold of sediment material motion.

Based on the test results, if a finer stone is used for the protection of the streambed around the pier, some riprap materials are washed away and scour hole is developed. However, the remaining stones slide into the scour hole and armor it. Therefore, the scour hole is stabilized, and its final depth will be less than the equilibrium scour depth for the unprotected pier depending on the riprap size.

Experiments showed that, with coarser material (smaller $B / D_{50}$ ) closer to the stable riprap size, the efficiency of round and angular materials was identical. With finer riprap sizes, e.g., $B / D_{50}=12$, scour depth was about $17 \%$ greater in round shape riprap material than that in angular shape stones. Experimental 
Table 7. Riprap size with different conditions for bridge site over Homochitto and Brazos rivers (in meter).

\begin{tabular}{ccccccccc}
\hline & \multicolumn{2}{c}{ For oval extent } & & \multicolumn{2}{c}{$\begin{array}{c}\text { For angular shape } \\
\text { and circular extent }\end{array}$} & & \multicolumn{2}{c}{$\begin{array}{c}\text { For round shape } \\
\text { and circular extent }\end{array}$} \\
\cline { 2 - 3 } $\boldsymbol{d}_{\boldsymbol{s}} / \boldsymbol{d}_{\text {se }} \boldsymbol{y}$ & $\begin{array}{c}\text { Homochitto } \\
\text { River }\end{array}$ & $\begin{array}{c}\text { Brazos } \\
\text { River }\end{array}$ & & $\begin{array}{c}\text { Homochitto } \\
\text { River }\end{array}$ & $\begin{array}{c}\text { Brazos } \\
\text { River }\end{array}$ & & $\begin{array}{c}\text { Homochitto } \\
\text { River }\end{array}$ & $\begin{array}{c}\text { Brazos } \\
\text { River }\end{array}$ \\
\hline 0.0 & 0.155 & 0.056 & & 0.155 & 0.056 & & 0.155 & 0.056 \\
0.1 & 0.135 & 0.049 & & 0.138 & 0.050 & & 0.141 & 0.051 \\
0.2 & 0.120 & 0.044 & & 0.124 & 0.045 & & 0.130 & 0.047 \\
0.3 & 0.108 & 0.039 & & 0.114 & 0.041 & & 0.121 & 0.044 \\
0.5 & 0.091 & 0.033 & & 0.098 & 0.035 & & 0.106 & 0.038 \\
\hline
\end{tabular}

results also showed that if the stable riprap size (that is $100 \%$ protection) decreases by about $40 \%$ to $45 \%$ depending on the angularity and extent of the riprap layer, about $50 \%$ of maximum scour hole occurs.

Finally, based on experimental data, a new modification factor was applied to the equation presented by Karimaei Tabarestani and Zarrati (2015b) [15] in order to calculate a smaller riprap size based on an accepted limited scour hole.

\section{References}

1. Raudkivi, A., Loose Boundary Hydraulics, A.A. Balkema, Rotterdam, Brookfield, Netherlands (1998).

2. Karimaei Tabarestani, M. and Zarrati, A.R. "Local scour calculation around bridge pier during flood event", KSCE J. Civil Eng., 21(4), pp. 1462-1472 (2017).

3. Zarrati, A.R., Nazariha, M., and Mashahir, M.B. "Reduction of local scour in the vicinity of bridge pier groups using collars and riprap", J. Hydraul. Eng., 132(2), pp. 154-162 (2006).

4. Karimaei Tabarestani, M. and Zarrati, A.R. "Effect of collar on time development and extent of scour hole around cylindrical bridge piers", Int. J. Eng., Transactions $C, \mathbf{2 5}(1)$, pp. 11-16 (2011).

5. Melville, B.W. and Hadfield, A.C. "Use of sacrificial piles as pier scour countermeasures", J. Hydraul. Eng., 125(11), pp. 1221-1224 (1999).

6. Chiew, Y.M. "Scour protection at bridge piers", J. Hydraul. Eng., 118(9), pp. 1260-1269 (1992).

7. Gaudio, R., Tafarojnoruz, A., and Calomino, F. "Combined flow-altering countermeasures against bridge pier scour", J. Hydraul. Res., 50(1), pp. 35-43 (2012).

8. Tafarojnoruz, A., Gaudio, R., and Calomino, F. "Evaluation of flow-altering countermeasures against bridge pier scour", J. Hydraul. Eng., 138(3), pp. 297-305 (2012).

9. Chiew, Y.M. "Mechanics of riprap failure at bridge pier", J. Hydraul. Eng., 121(9), pp. 635-643 (1995).
10. Richardson, E.V. and Davis, S.R. "Evaluating scour at bridges", Hydraul. Eng. Circular, No. 18 (HEC-18 Fourth Edition), FHWA NHI 01-001, Federal Highway Administration, Washington, D.C. (2001).

11. Lagasse, P.F., Clopper, P.E., Zevenbergen, L.W., and Girard, L.G. "Countermeasures to protect bridge piers from scour", NCHRP Report 593, TRB, NAS, Washington D.C. (2007).

12. Mashahir, M.B., Zarrati, A.R., and Mokallaf, E. "Application of riprap and collar to prevent scouring around piers rectangular bridge", J. Hydraul. Eng., 136(3), pp. 183-187 (2009).

13. Karimaei Tabarestani, M. and Zarrati, A.R. "Design of stable riprap around aligned and skewed rectangular bridge piers", J. Hydraul. Eng., 139(8), pp. 911-916 (2013).

14. Karimaei Tabarestani, M. and Zarrati, A.R. "Design of riprap stone around bridge piers using empirical and neural network method", Civil Eng. Infrast. J., 48(1), pp. 175-188 (2015a).

15. Karimaei Tabarestani, M., Zarrati, A.R., Mashahir, M.B., and Mokallaf, E. "Extent of riprap layer with different stone sizes around rectangular bridge piers with or without an attached collar", Scientia Iranica, Trans. A, 22(3), pp. 709-716 (2015b).

16. Karimaei Tabarestani, M., Azarmidokht, H.R., Zarrati, A.R., and Anvary, S. "Optimum design of riprap extension with different stone size at rectangular bridge piers with and without protective collar", $I$. Hydraul. J., 10(4), pp. 51-64 (2016) (In Persian).

17. Froehlich, D.C. "Protecting bridge piers with loose rock riprap", J. App. Wat. Eng. \& Res., 1(1), pp. 3957 (2013).

18. Chiew, Y.M. and Lim, F.H. "Failure behavior of riprap layer at bridge piers under live-bed condition", $J$. Hydraul. Eng., 126(1), pp. 43-55 (2000).

19. Chiew, Y.M. "Local scour and riprap stability at bridge piers in a degrading channel", J. Hydraul. Eng., 130(3), pp. 218-226 (2004).

20. Lauchlan, C.S. and Melville, B.W. "Riprap protection at bridge piers", J. Hydraul. Eng., 127(5), pp. 412-418 (2001). 
21. Unger, J. and Hager, W.H. "Riprap failure at circular

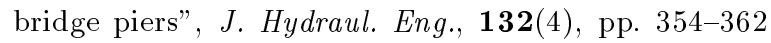
(2006).

22. Rajaratnam, N. and Nwachukwu, B.A. "Erosion near groynelike structures" J. Hydraul. Res., 21(4), pp. 277-287 (1983).

23. Oliveto, G. and Hager, W.H. "Temporal evolution of clear-water pier and abutment scour", J. Hydraul. Eng., 128(9), pp. 811-820 (2002).

24. Garde, R.J. and Ranga Raju, K.G., Mechanics of Sediment Transportation and Alluvial Stream Problems, Wiley Eastern Limited, New Delhi (1977).

25. Raudkivi, A. and Ettema, R. "Effect of sediment gradation on clear water scour", J. Hydraul. Div., 103(HY10), pp. 1209-1213 (1977).

26. Melville, B.W. and Sutherland, A.J. "Design method for local scour at bridge piers", J. Hydraul. Eng., 114(10), pp. 1210-1226 (1988).

\section{Biographies}

Gholamnabi Khademghaeiny received both his BSc in Civil Engineering and MSc in Hydraulic Structure from Ferdowsi University of Mashhad. He is currently working in Project Management sector at consultant engineering companies.

Jalil Abrishami was a faculty member of Ferdowsi University of Mashhad in Hydraulic Engineering before retirement. His research interests are hydraulic structures including stilling basins and spillways, seepage in dam foundation, groundwater modeling, drainage in dam bodies and scour protection in rivers and bridge piers and abutments. Dr Abrishami is currently cooperating with Eshragh Institute of higher education in Bojnoord, I.R. Iran .

Amir Reza Zarrati is a Professor of Hydraulic Engineering at the Department of Civil and Environmental Engineering, Amirkabir University of Technology Tehran, Iran. He has more than 25 years of teaching and research experience. His main area of research is numerical and physical modeling of flow behavior such as that in hydraulic structures and rivers. He is also interested in scouring phenomenon and methods of its control. Dr. Zarrati has also a long record of collaboration with industry and has been a senior consultant for a number of large dams in the country. He is a member of Iranian Hydraulic Association (IHA) and International Association of Hydraulic Research (IAHR).

Mojtaba Karimaei Tabarestani received his MSc and $\mathrm{PhD}$ from Amirkabir University of Technology and is currently an Assistant Professor in Hydraulic Engineering at the Department of Civil Engineering, Shahid Rajaee Teacher Training University Tehran, Iran. His main area of research is physical modeling of flow behavior, such as that in hydraulic structures and rivers. He is also interested in mechanics of sediment transport and scouring phenomenon and its protection in river training structures and bridges. He is a member of Iranian Hydraulic Association (IHA).

Mohammad Mashahir received his BSc in Water Engineering from Tabriz University and his MSc in Hydraulic Engineering from Amirkabir University of Technology. Mr Mashahir has vast experience in consulting engineering companies and is currently pursuing his education to a $\mathrm{PhD}$ level in Amirkabir University. 